\title{
Prototipe Cranial Electrotherapy Stimulation
}

\author{
Firman Firjatullah* ${ }^{1}$, Muhammad $\operatorname{Irfan}^{2}$ \\ ${ }^{1}$ Program Studi Teknologi Elektro-medis Program Vokasi, Universitas Muhammadiyah Yogyakarta, Indonesia \\ ${ }^{2}$ Rumah Sakit PKU Muhammadiyah Gamping, Yogyakarta, Indonesia
}

INFO ARTIKEL

Alamat Web Artikel:

https://journal.umy.ac.id/index.php/ $\mathrm{mt} /$ article/view/12228

DOI:

https://doi.org/10.18196/mt.v3i1.12 228

Data Artikel:

Diterima:

07 Juli 2021

Direview:

30 Agustus 2021

Direvisi :

30 September 2021

Disetujui :

07 Oktober 2021

Korespondensi:

firman.f.vok17@mail.umy.ac.id

\begin{abstract}
ABSTRAK
Cranial Electrotherapy Stimulator merupakan alat kedokteran yang berfungsi untuk terapi. Alat ini bekerja dengan cara memberikan arus listrik melalui kepala pasien untuk mengobati insomnia, depresi dan ansietas (anxiety) melalui elektroda yang dipasang pada daun telinga (earlobes) dengan menggunakan arus listrik yang sangat rendah. Adanya sifat arus kelistrikan pada tubuh manusia memungkinkan kita dapat memberikan rangsangan ke dalam tubuh manusia secara langsung. Tujuan dari penelitian ini adalah mengembangkan Prototype Cranial Electrotherapy Stimulation yang diharapkan dapat mengatasi penyakit depresi, insomnia dan ansietas. Prototipe Cranial Electrotherapy Stimulation menggunakan elektroda earclip sebagai media output terapi dan OLED 96 inch sebagai display timer dan menu. Rangkaian utama Prototipe Cranial Electrotherapy Stimulation terdiri dari rangkaian minimum sistem ATMega328P, rangkaian pembangkit frekuensi, dan rangkaian battery level. Pada pengujian frekuensi output didapatkan hasil rata-rata nilai frekuensi sebesar $0,5021 \mathrm{~Hz}$ dengan persentase error sebesar $0,42 \%$. Pada pengujian arus didapatkan range rata-rata sebesar $68,15 \mu \mathrm{A}-744,9 \mu \mathrm{A}$ dengan rata-rata arus titik default sebesar $100,2 \mu \mathrm{A}$. Pada pengujian lain seperti pengujian spesifikasi gelombang dan kepresisian timer diketahui jenis gelombang berupa gelombang kotak dengan tinggi gelombang $9 \mathrm{Vp}$ dan durasi positif $400 \mathrm{~ms}-500 \mathrm{~ms}$, timer pada alat pun sangat presisi karena tidak memiliki nilai error lebih dari 1 detik.
\end{abstract}

Kata Kunci: Anxiety, ATMega328P, Cranial Electrotherapy Stimulation, Depresi, dan Insomnia

\begin{abstract}
Cranial electrotherapy stimulator is a medical device that functions for therapy by providing an electric current through the patient's head to treat insomnia, depression and anxiety through electrodes mounted on the earlobe (earlobes) using very low electric currents. The electrical current system in the human body allows us to provide stimulation into the human body directly. Prototype Of Cranial Electrotherapy Stimulation using earclip electrodes as the output media of therapy and 96 inch OLED as a display timer and menu. The main circuit of Prototype Cranial Electrotherapy Stimulation consists of a minimum systems ATMega328P, frequency generators, and battery level. In the output frequency test, the average frequency value was $0.5021 \mathrm{~Hz}$ with an error percentage of $0.42 \%$. In the current test, it was obtained an average range of $68.15 \mu \mathrm{A}-744.9 \mu \mathrm{A}$ with an average default point current of $100.2 \mu \mathrm{A}$. In other tests such as testing of wave specifications and timer precision, it is known that the type of wave is a square wave with a wave height of $9 \mathrm{Vp}$ and a positive duration of $400 \mathrm{~ms}-500 \mathrm{~ms}$, the timer on the tool is very precise because it does not have an error value of more than 1 second.
\end{abstract}

Keywords: Anxiety, ATMega328P, Cranial Electrotherapy Stimulation, Depression and Insomnia

\section{PENDAHULUAN}

Pada jaman sekarang stres dan depresi bisa menimpa siapa saja. Hal tersebut disebabkan karena tekanan yang dialami oleh manusia baik itu tekanan ekonomi, sosial maupun lingkungan semakin meningkat di era modern ini. Tak hanya orang dewasa, masalah kesehatan mental juga semakin banyak dialami oleh remaja bahkan anak-anak. Dari hal ini tidak sedikit dari mereka mengalami gejala-gejala penyakit seperti insomnia, depresi, dan ansietas yang pada akhirnya bisa 
membuat manusia itu sendiri tidak mampu mempertahankan kesehatan bahkan kehidupannya. Menurut data, diperkirakan sekitar 300 juta orang mengidap depresi di seluruh dunia. Bahkan, World Health Organization (WHO) memperkirakan setiap 40 detik terjadi kasus bunuh diri di seluruh dunia yang diakibatkan oleh depresi. Ketua Perhimpunan Dokter Spesialis Kedokteran Jiwa Indonesia (PDSKJI), dr. Eka Viora, Sp.KJ, mengatakan di Indonesia terdapat sekitar 15,6 juta penduduk yang mengalami depresi. Sayangnya hanya 8 persen yang mencari pengobatan ke profesional. Untuk itu sesuai dengan pesatnya perkembangan teknologi dewasa ini, turut memacu perkembangan teknologi di bidang kesehatan yang efektif dan efesien [1]-[2]. Salah satu peralatan kesehatan tersebut yang digunakan dibagian physiotherapy yaitu Cranial Electrotherapy Stimulation yang biasanya terdapat pada Rumah Sakit yang memberikan pelayanan di bagian neurology dan physikiatri [3].

Dalam bidang neurology dan physikiatri, Cranial Electrotherapy Stimulation digunakan untuk therapy dalam mengobati penyakit insomnia, depresi, maupun kecemasan dengan cara memberikan arus listrik ke kepala pasien melalui elektroda yang dipasang pada daun telinga dengan arus yang sangat rendah, biasanya tidak lebih dari $1 \mathrm{~mA}$ dan dengan frekuensi 0,5 [4]. Alat Cranial Electrotherapy Stimulation ini juga biasa digunakan oleh dokter untuk memberikan rasa nyaman kepada pasien saat dilakukan pemeriksaan atau pengobatan [5].

Sebelum terciptanya Cranial Electrotherapy Stimulation banyak orang mengambil keputusan untuk mengatasi penyakit insomnia, depresi maupun kecemasan atau ansietas dengan obat-obat penenang dan obat tidur [5]. Tapi karena obat-obat penenang dan obat tidur menyebabkan ketergantungan maka dirancang Cranial Electrotherapy Stimulation dengan system digital yang hanya dapat digunakan dengan bantuan operator atau dokter. Kemudian dikembangkan kembali Cranial Electrotherapy Stimulation dengan system mikrokontroler yang lebih efektif dan efesien sehingga alat ini juga dapat dimiliki oleh pasien tanpa bantuan operator [6],[7].

Dari hasil pemaparan diatas, akan dirancang "Prototipe Cranial Electrotherapy Stimulation" dimana modul ini dapat digunakan sebagai gambaran dan pengembangan awal alat terapi yang efektif dan efisien mengatasi insomnia, depresi dan ansietas secara optimal dan tanpa efek samping.

\section{METODE PENELITIAN}

\subsection{Alat}

Tabel 1 menunjukkan alat yang akan digunakan ketika melakukan perancangan Prototipe Cranial Electrotherapy Stimulation.

Tabel 1. Alat

\begin{tabular}{|c|c|c|}
\hline No & Nama Alat & Jumlah \\
\hline 1 & Laptop & 1 \\
\hline 2 & Tool Set & 1 \\
\hline 3 & Solder & 1 \\
\hline 4 & Kabel Data & 1 \\
\hline 5 & Osiloskop & 1 \\
\hline 6 & Bor & 1 \\
\hline 7 & Multimeter & \\
\hline
\end{tabular}

\subsection{Bahan}

Tabel 2 menunjukkan bahan yang akan digunakan ketika melakukan perancangan Prototipe Cranial Electrotherapy Stimulation. 
Firjatullah, Irfan

Prototipe Cranial Electrotherapy Stimulation

Tabel 2. Bahan

\begin{tabular}{|c|c|c|}
\hline No & Nama Alat & Jumlah \\
\hline 1 & PCB (Printed Circuit Board) & Seperlunya \\
\hline 2 & IC ATMega328 & 1 \\
\hline 3 & Minimum System & 1 \\
\hline 4 & IC NE555 & 1 \\
\hline 5 & IC 7015 & 1 \\
\hline 6 & IC LM 3914 & 1 \\
\hline 7 & LED & 5 \\
\hline 8 & Push Button & 5 \\
\hline 9 & Elektroda Ear Clip & 2 \\
\hline 10 & Baterai 9 Volt & 1 \\
\hline 11 & Charger & 1 \\
\hline 12 & Jumper Male/Female & Seperlunya \\
\hline 13 & Timah & Seperlunya \\
\hline 14 & OLED & 1 \\
\hline 15 & Board Akrilik & Seperlunya \\
\hline 16 & Jack DC Male & 1 \\
\hline 17 & Jack DC Female & 1 \\
\hline 18 & Connector Micro to Type C & 1 \\
\hline 19 & Stiker & Seperlunya \\
\hline 20 & Spacer $1 \mathrm{~cm}$ & 4 \\
\hline 21 & Lem Lilin & Seperlunya \\
\hline 22 & Komponen Elektronika lain & Seperlunya \\
\hline
\end{tabular}

\subsection{Rangkaian Keseluruhan}

Perancangan Prototipe Cranial Electrotherapy Stimulation dilakukan dengan tahap desain rangkaian yang ditunjukkan pada Gambar 1. Pada gambar dapat dilihat bahwa rangkaian keseluruhan terdiri atas rangkaian minimum sistem, rangkaian display OLED sebagai penampil pada layar, rangkaian indikator level baterai, rangkaian push button dan rangkaian pembangkit frekuensi.

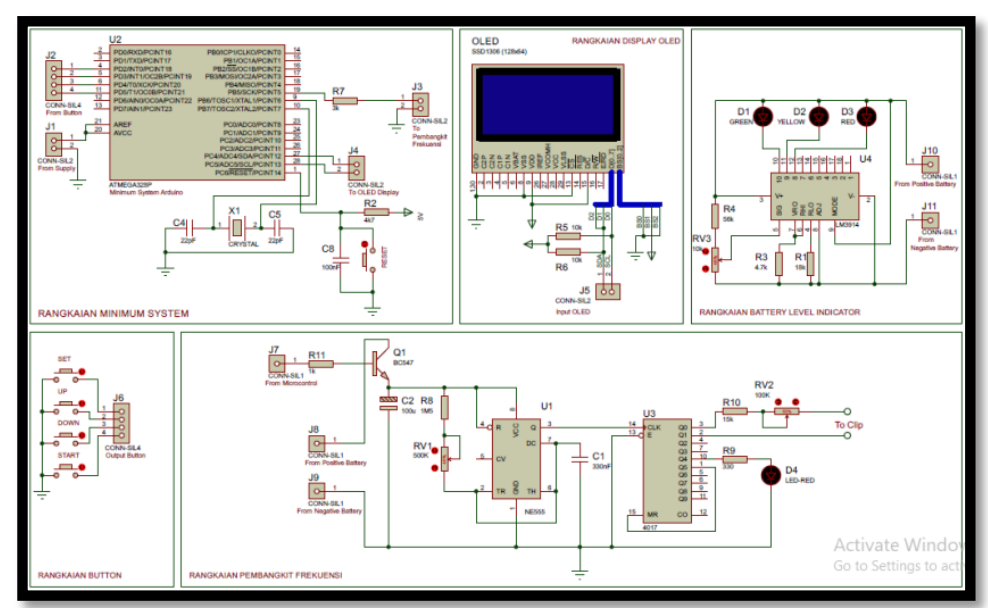

Gambar 1. Skematik Rangkaian Keseluruhan

Medika Teknika : Jurnal Teknik Elektromedik Indonesia, Vol 03 No. 1, Oktober $2021 \mid 25$ 


\section{Firjatullah, Irfan}

Prototipe Cranial Electrotherapy Stimulation

Perancangan diagram blok Prototipe Cranial Electrotherapy Stimulation dilakukan dengan tahap desain diagram blok yang ditunjukkan pada Gambar 2. Pada gambar dapat dilihat bahwa rangkaian keseluruhan terdiri atas mikrokontroler, display OLED sebagai penampil pada layar, indikator level baterai, push button dan pembangkit frekuensi.

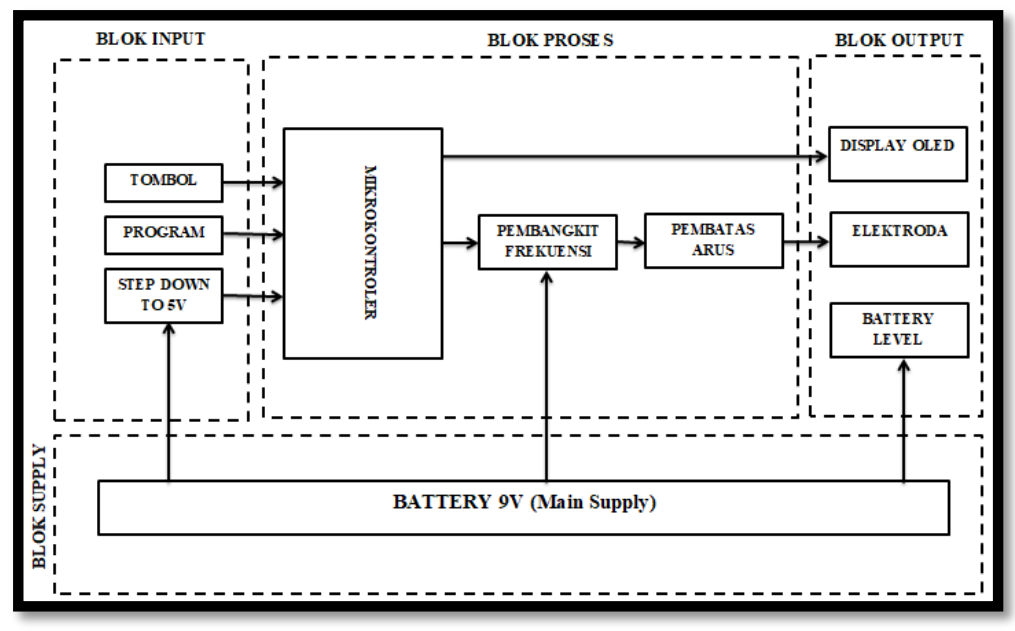

Gambar 2. Diagram Blok

\section{HASIL DAN PEMBAHASAN}

\subsection{Pengujian Frekuensi Output}

Hasil dari pengujian nilai frekuensi dapat dilihat pada Tabel 3 berikut.

Tabel 3. Tabel Pengujian Nilai Frekuensi Output

\begin{tabular}{|c|c|c|}
\hline Pengujian Ke- & $\begin{array}{l}\text { Ketetapan Standar Nilai } \\
\text { Frekuensi Output }\end{array}$ & $\begin{array}{c}\text { Nilai Frekuensi yang } \\
\text { Terukur }\end{array}$ \\
\hline 1 & \multirow{10}{*}{$0,5 \mathrm{~Hz}[4][7][8][9]$} & $0,5016 \mathrm{~Hz}$ \\
\hline 2 & & $0,5034 \mathrm{~Hz}$ \\
\hline 3 & & $0,5017 \mathrm{~Hz}$ \\
\hline 4 & & $0,5027 \mathrm{~Hz}$ \\
\hline 5 & & $0,503 \mathrm{~Hz}$ \\
\hline 6 & & $0,5015 \mathrm{~Hz}$ \\
\hline 7 & & $0,5036 \mathrm{~Hz}$ \\
\hline 8 & & $0,501 \mathrm{~Hz}$ \\
\hline 9 & & $0,5012 \mathrm{~Hz}$ \\
\hline 10 & & $0,5013 \mathrm{~Hz}$ \\
\hline \multicolumn{2}{|c|}{ Nilai Rata-Rata } & $0,5021 \mathrm{~Hz}$ \\
\hline \multicolumn{2}{|c|}{ Simpangan } & $0,0021 \mathrm{~Hz}$ \\
\hline \multicolumn{2}{|c|}{ Persentase Error } & $+0,42 \%$ \\
\hline \multicolumn{2}{|c|}{ Persentase Akurasi } & $99,58 \%$ \\
\hline
\end{tabular}

Berdasarkan hasil pada Tabel 3 dapat dianalisa bahwa pada pengukuran frekuensi sebanyak 10 kali didapatkan hasil rata-rata sebesar $0,5021 \mathrm{~Hz}$ sehingga dapat dihitung nilai simpangan antara nilai standar dan nilai terukur sebesar $0,0021 \mathrm{~Hz}$ dengan persentase error sebesar $+0,42 \%$. Dari data tersebut dapat dikatakan bahwa alat Prototipe Cranial Electrotherapy Stimulation yang dibuat memiliki error kurang dari $5 \%$ dan memiliki akurasi sebesar 99,58 \%. Faktor yang memungkinkan menyebabkan nilai error adalah ketidakstabilan rangkaian dan kondisi spesifikasi dari setiap komponen elektonika yang digunakan pada board rangkaian. 


\section{Firjatullah, Irfan}

Prototipe Cranial Electrotherapy Stimulation

\subsection{Pengujian Arus Output}

Hasil dari pengujian nilai arus dapat dilihat pada Tabel 4 berikut.

Tabel 4. Tabel Pengujian Arus Output

\begin{tabular}{|c|c|c|c|c|c|c|c|}
\hline \multirow{4}{*}{ No } & \multirow{4}{*}{$\begin{array}{l}\text { Ketetapan Standar } \\
\text { Nilai Arus Output }\end{array}$} & \multicolumn{6}{|c|}{ Nilai Arus yang Terukur $(\mu \mathrm{A})$} \\
\hline & & \multicolumn{2}{|c|}{ Batas Bawah } & \multicolumn{2}{|c|}{ Batas Atas } & \multicolumn{2}{|c|}{ Default } \\
\hline & & Tanpa & Dengan & Tanpa & Dengan & Tanpa & Dengan \\
\hline & & Beban & Beban & & Beban & & \\
\hline 1 & \multirow{10}{*}{$\begin{array}{c}68 \mu \mathrm{A}-740 \mu \mathrm{A} \\
\text { (Range Arus) } \\
100 \mu \mathrm{A} \\
\text { (Nilai Default)[10] } \\
\text { Ketentuan Lain : } \\
\text { Tidak lebih dari } \\
1 \mathrm{~mA}[7][8][9]\end{array}$} & 68,3 & 67,21 & 743,8 & 669,7 & 100,1 & 95,2 \\
\hline 2 & & 68,2 & 67,28 & 743,8 & 667,8 & 99,3 & 94,77 \\
\hline 3 & & 68,3 & 67,15 & 743,7 & 672,8 & 101 & 94,8 \\
\hline 4 & & 68,1 & 67,29 & 746,3 & 665,5 & 99,1 & 94,6 \\
\hline 5 & & 67,9 & 67 & 745,2 & 664,8 & 100,6 & 96,7 \\
\hline 6 & & 68,1 & 67,35 & 745,5 & 666,6 & 99,24 & 96,3 \\
\hline 7 & & 67,9 & 67,22 & 744,3 & 669,8 & 98,7 & 96,7 \\
\hline 8 & & 68,2 & 67,31 & 744,8 & 672,2 & 101,9 & 96,2 \\
\hline 9 & & 68,2 & 67,14 & 745,7 & 674,5 & 100,5 & 96,03 \\
\hline 10 & & 68,3 & 67,2 & 745,9 & 660,8 & 101,6 & 94,7 \\
\hline & Nilai Rata-Rata & 68,15 & 67,21 & 744,9 & 668,45 & 100,2 & 95,6 \\
\hline & Simpangan & 0,15 & $-0,78$ & 4,9 & $-71,55$ & 0,2 & $-4,4$ \\
\hline & Error & $0,22 \%$ & $1,14 \%$ & $0,66 \%$ & $9,6 \%$ & $0,2 \%$ & $4,4 \%$ \\
\hline
\end{tabular}

Berdasarkan hasil pada Tabel 4 dapat dianalisa bahwa pada pengukuran arus sebanyak 10 kali pada kondisi tanpa beban didapatkan hasil rata-rata sebesar 68,16 $\mu \mathrm{A}$ (nilai error : $0,22 \%$ ) untuk batas bawah, $744,9 \mu \mathrm{A}$ (nilai error: $0,66 \%$ ) untuk batas atas dan 100,2 $\mu \mathrm{A}$ (nilai error:0,2\%) untuk titik default, dari data tersebut dapat dikatakan bahwa nilai arus yang terukur sudah sesuai dimana range tersebut masih masuk ke dalam range arus alat asli dengan merk Alpha-Stim. Sedangkan pada kondisi diberikan beban (beban: $1000 \mathrm{ohm}$ ) didapatkan nilai rata-rata arus sebesar 67,21 $\mu$ A (nilai error : 1,14\%) untuk batas bawah, $668,45 \mu \mathrm{A}$ (nilai error: 9,6 \%) untuk batas atas dan $96,6 \mu$ A (nilai error:4,4\%) untuk titik default. Selain itu nilai batas atas arus tidak melebihi 1 $\mathrm{mA}$ yang mana hal tersebut sesuai dengan teori dasar dan beberapa jurnal terdahulu.

\subsection{Pengujian Kepresisian Timer}

Hasil dari pengujian kepresisian timer dapat dilihat pada Tabel 5 berikut.

Tabel 5. Tabel Pengujian Kepresisian Timer

\begin{tabular}{|c|c|c|c|c|}
\hline $\begin{array}{l}\text { Nilai } \\
\text { Setting }\end{array}$ & $\begin{array}{c}\text { Nilai Sebenarnya } \\
\text { (dalam menit dan detik) }\end{array}$ & Simpangan & $\begin{array}{l}\text { Toleransi } \\
\text { Simpangan }\end{array}$ & Keterangan \\
\hline 5 Menit & $05: 00$ & - & \multirow{9}{*}{1 Menit } & Laik \\
\hline 10 Menit & $09: 59$ & 1 Detik & & Laik \\
\hline 15 Menit & $14: 59$ & 1 Detik & & Laik \\
\hline 20 Menit & $20: 00$ & - & & Laik \\
\hline 25 Menit & $24: 59$ & 1 Detik & & Laik \\
\hline 30 Menit & $29: 59$ & 1 Detik & & Laik \\
\hline 35 Menit & $34: 59$ & 1 Detik & & Laik \\
\hline 40 Menit & $39: 59$ & 1 Detik & & Laik \\
\hline 45 Menit & $40: 00$ & 1 Detik & & Laik \\
\hline
\end{tabular}

Berdasarkan Tabel 5 ditunjukkan bahwa simpangan yang terjadi pada timer rata-rata sebesar 1 detik, sehingga dapat disimpulkan bahwa timer berjalan dengan sangat presisi. 
Firjatullah, Irfan

Prototipe Cranial Electrotherapy Stimulation

\subsection{Pengujian Nilai Tegangan atau Tinggi Gelombang Output}

Hasil dari pengujian nilai tegangan dapat dilihat pada Tabel 6 berikut.

Tabel 6. Tabel Pengujian Tegangan dan Tinggi Gelombang Output

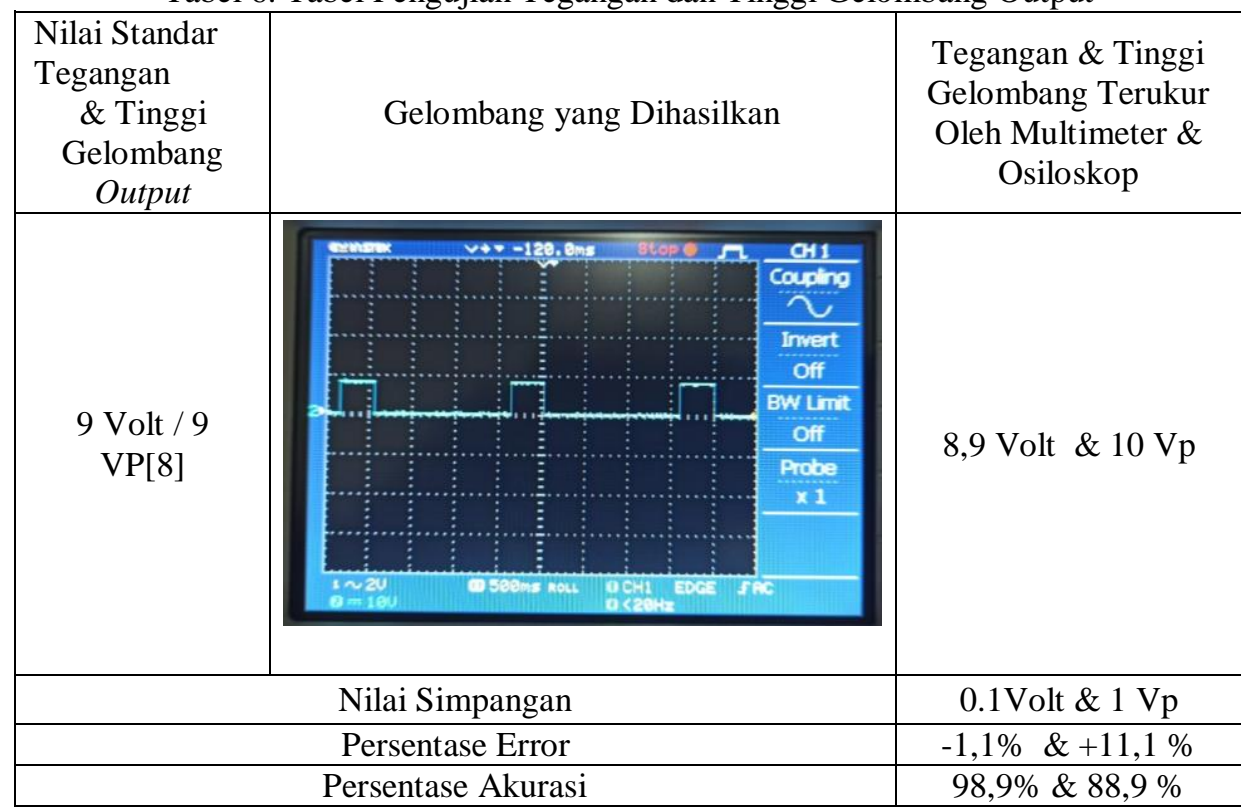

Berdasarkan hasil pada Tabel 6 dapat dianalisa bahwa pada pengukuran tegangan output atau tinggi gelombang output didapat hasil terbaca oleh multimeter dan osiloskop sebesar 8,9 Volt dan $10 \mathrm{Vp}$, sehingga nilai terbaca memiliki selisih atau nilai simpangan sebesar 0,1 Volt (error: $-1,1 \%$ ) untuk pembacaan tegangan dan $1 \mathrm{Vp}$ (error: $+11,1 \%)$ untuk pembacaan tinggi gelombang dari nilai standar yang penulis ambil dari sebuah jurnal yaitu sebesar 9 Volt / 9 Vp. Meski tegangan dan tinggi gelombang secara kasar tidak terlalu berperan penting dalam aspek terapi karena selagi ada efek kejutan yang terasa oleh pasien maka tegangan yang digunakan bisa dikatakan cukup dan bisa digunakan. Meski begitu, pada pengujian ini dapat disimpulkan bahwa ada kemungkinan terjadi kesalahan pada alat ukur multimeter atau osiloskop dimana seharusnya nilai yang terbaca oleh multimeter dan osiloskop memberikan nilai yang sama yaitu sebesar 9 Volt/9VP. Kesalahan ini juga dapat dikarenakan kesalahan pembacaan nilai oleh penulis karena nilai tegangan yang ditampilkan pada multimeter tidak tetap (naik-turun) karena bentuk gelombang output yang flipflop.

\subsection{Membaca dan Membandingkan Bentuk Gelombang Output}

Hasil dari pembacaan bentuk gelombang dapat dilihat pada Tabel 7 berikut.

Tabel 7. Tabel Hasil Pembacaan Bentuk Gelombang Output

\begin{tabular}{|c|c|c|}
\hline \multicolumn{3}{|c|}{ Gambar Gelombang Output } \\
\hline \multicolumn{2}{|c|}{ 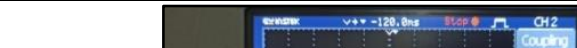 } & \\
\hline Jenis Gelombang & Durasi & Frekuensi \\
\hline $\begin{array}{c}\text { DC putus-putus } \\
\text { (Rectangular) / monophasic } \\
\text { pulse }\end{array}$ & $\begin{array}{c}400- \\
500 \mathrm{~ms}\end{array}$ & $0,5 \mathrm{~Hz}$ \\
\hline
\end{tabular}

Medika Teknika : Jurnal Teknik Elektromedik Indonesia, Vol 03 No. 1, Oktober 2021 | 28 
Berdasarkan Tabel 7 diatas dapat dianalisis bahwa gelombang output alat Prototipe Cranial Electrotherapy Stimulation sudah memenuhi syarat untuk dapat melakukan stimulasi dimana syarat-syarat gelombang listrik untuk melakukan stimulasi atau memberikan kontraksi diantaranya: Intensitas arus tidak menetap (modifikasi intensitas) dengan durasi bernilai anatara $0,01 \mathrm{~ms}$ - $1000 \mathrm{~ms}$ (modifikasi durasi) dan adanya modifikasi frekuensi [7]. Jenis gelombang output alat Prototipe Cranial Electrotherapy Stimulation pun sudah termasuk ke kelompok gelombang yang dapat menstimulasi atau merangsang saraf sensorik dan saraf motorik yaitu jenis gelombang interputus kotak atau monophasic pulse rectangular.

\subsection{Pengambilan Data dari Pengguna}

Data yang diambil dari pengalaman pengguna dapat dilihat pada Tabel 8 berikut.

Tabel 8. Tabel Pengalaman Pengguna

\begin{tabular}{|c|c|c|c|c|c|c|}
\hline \multirow{2}{*}{ No } & \multirow{2}{*}{ Nama } & \multirow{2}{*}{ NIM } & \multirow{2}{*}{ Durasi } & \multicolumn{3}{|c|}{ Pengalaman Pengguna Per Batas Arus } \\
\hline & & & & Batas Bawah & Default & Batas Atas \\
\hline 1 & $\begin{array}{l}\text { Firman } \\
\text { Firjatullah }\end{array}$ & 20173010051 & 1 Menit & $\begin{array}{l}\text { Denyutan } \\
\text { ringan } \\
\text { disekitar } \\
\text { elektroda }\end{array}$ & $\begin{array}{c}\text { Denyutan } \\
\text { menguat dengan } \\
\text { sensasi kesemutan } \\
\text { yang } \\
\text { menyenangkan }\end{array}$ & $\begin{array}{l}\text { Denyutan terasa } \\
\text { sangat kuat } \\
\text { dengan sensasi } \\
\text { menusuk di } \\
\text { sekitar elektroda }\end{array}$ \\
\hline 2 & $\begin{array}{c}\text { Muhamma } \\
\text { d Tri } \\
\text { Cahyo }\end{array}$ & 20173010048 & 1 Menit & $\begin{array}{l}\text { Denyutan } \\
\text { tidak terasa }\end{array}$ & $\begin{array}{l}\text { Denyutan ringan } \\
\text { terasa dengan } \\
\text { sensasi kesemutan } \\
\text { yang } \\
\text { menyenangkan }\end{array}$ & $\begin{array}{l}\text { Denyutan terasa } \\
\text { lebih kuat di } \\
\text { sekitar elektroda }\end{array}$ \\
\hline 3. & $\begin{array}{l}\text { Ade Imam } \\
\text { Dermawan }\end{array}$ & 20173010039 & 1 Menit & $\begin{array}{c}\text { Denyutan } \\
\text { terasa sangat } \\
\text { lemah di salah } \\
\text { satu elektroda }\end{array}$ & $\begin{array}{c}\text { Denyutan ringan } \\
\text { terasa dengan } \\
\text { sensasi kesemutan } \\
\text { yang } \\
\text { menyenangkan }\end{array}$ & $\begin{array}{l}\text { Denyutan terasa } \\
\text { lebih kuat di } \\
\text { sekitar elektroda }\end{array}$ \\
\hline 4. & Ilham & 20173010020 & 1 Menit & $\begin{array}{l}\text { Denyutan } \\
\text { tidak terasa }\end{array}$ & $\begin{array}{c}\text { Denyutan terasa } \\
\text { sangat lemah }\end{array}$ & $\begin{array}{c}\text { Denyutan terasa } \\
\text { lebih kuat dengan } \\
\text { sensasi kesemutan } \\
\text { di sekitar } \\
\text { elektroda } \\
\end{array}$ \\
\hline
\end{tabular}

Dari keempat pengguna dapat dilihat bahwa efek yang dirasakan pengguna pada menit pertama sama dengan pemaparan pengalaman menit pertama pengguna alat Cranial Electrotherapy Stimulator yang asli atau yang beredar dipasaran, dimana dirasakannya denyutan dara perasaan tingling disekitar elektroda dan tidak dirasakannya efek samping seperti sakit kepala, vertigo dan iritasi kulit. Karena setiap manusia memiliki resistansi yang berbeda-beda yang mana resistansi tersebut dipengaruhi oleh berbagai faktor seperti kelembapan kulit, usia dan jenis kulit, hal itu menyebabkan antar pengguna merasakan kekuatan denyutan yang berbeda di setiap tingkatan arusnya.

\section{KESIMPULAN}

Berdasarkan hasil penelitian yang telah dilakukan dapat disimpulkan bahwa:

a. Alat Prototipe Cranial Electrotherapy Stimulation dapat berfungsi dengan baik setelah dilakukan beberapa parameter pengujian dan pengambilan data yang terdiri dari pengujian nilai frekuensi output, nilai arus output, nilai tegangan dan tinggi gelombang output, perbandingan bentuk gelombang, kepresisian timer, dan pengujian untuk mendeteksi adanya stimulasi denyutan kepada manusia.

b. Pada pengujian nilai frekuensi output didapatkan hasil rata-rata sebesar $0,5021 \mathrm{~Hz}$ sehingga dengan selisih sebesar $0,0021 \mathrm{~Hz}$ dan persentase error sebesar $+0,42 \%$. Dari data tersebut dapat dikatakan bahwa alat Prototipe Cranial Electrotherapy Stimulation

Medika Teknika : Jurnal Teknik Elektromedik Indonesia, Vol 03 No. 1, Oktober 2021| 29 
yang penulis buat lolos dalam pengujian frekuensi karena persentase error yang kurang dari $5 \%$ dan memiliki persentase akurasi yang besar yaitu sebesar 99,58 \% .

c. Pada pengujian nilai arus output yang dilakukan dengan pengambilan data sebanyak 10x didapatkan hasil rata-rata sebesar 68,16 $\mu \mathrm{A}$ (nilai error : 0,22 \%) untuk batas bawah, $744,9 \mu \mathrm{A}$ (nilai error: 0,66 \%) untuk batas atas dan 100,2 $\mu \mathrm{A}$ (nilai error:0,2 \%) untuk titik default, dari data tersebut dapat dikatakan bahwa nilai arus yang terukur sudah sesuai dimana range tersebut masih masuk kedalam range arus alat asli dengan merk AlphaStim. Sedangkan pada kondisi diberikan beban (beban: $1000 \mathrm{ohm}$ ) didapatkan nilai ratarata arus sebesar $67,21 \mu \mathrm{A}$ (nilai error : $1,14 \%$ ) untuk batas bawah, 668,45 $\mu \mathrm{A}$ (nilai error: 9,6 \%) untuk batas atas dan 96,6 $\mu$ A (nilai error:4,4 \%) untuk titik default. Selain itu nilai batas atas arus tidak melebihi $1 \mathrm{~mA}$ yang mana hal tersebut sesuai dengan teori dasar dan beberapa jurnal terdahulu.

d. Pada pengujian timer didapatkan nilai selisih rata-rata hanya sebesar 1 detik, sehingga dapat disimpulkan bahwa timer berjalan dengan presisi.

e. Pada pengujian tegangan dan tinggi gelombang output didapat hasil terbaca oleh multimeter dan osiloskop sebesar 8,9 Volt dan $10 \mathrm{VP}$, sehingga nilai terbaca memiliki selisih atau nilai simpangan sebesar 0,1 Volt (error: $-1,1 \%$ ) untuk pembacaan tegangan dan 1 VP (error: $+11,1 \%$ ). Nilai error kemungkinan terjadi karena kesalahan pada alat ukur multimeter atau osiloskop dimana seharusnya nilai yang terbaca oleh multimeter dan osiloskop memberikan nilai yang sama yaitu sebesar 9 Volt/9VP. Kesalahan ini juga dapat dikarenakan kesalahan pembacaan nilai oleh penulis karena nilai tegangan yang ditampilkan pada multimeter tidak tetap (naik-turun) karena bentuk gelombang output yang flip-flop.

f. Pada pengujian jenis dan spesifikasi gelombang output didapat jenis gelombang berupa DC putus-putus (Rectangular) / monophasic pulse dengan durasi positif 400-500 ms dan frekuensi $0,5 \mathrm{~Hz}$. Semua spesifikasi tersebut sudah memenuhi syarat agar dapat memberikan stimulasi.

g. Pada pengujian efek "menit pertama" yang dilakukan pada 4 orang didapat hasil empat orang tersebut dapat merasakan efek seperti denyutan dan perasaan tingling disekitar elektroda.

\section{DAFTAR PUSTAKA}

[1] E. W. Ningsih, H. R. Fajrin, and A. Fitriyah, "Pendeteksi Hemoglobin Non Invasive," Med. Tek. J. Tek. Elektromedik Indones., vol. 1, no. 1, 2019, doi: 10.18196/mt.010102.

[2] E. Loniza and I. Syabani, "Portable Turbidimeter Dilengkapi Penyimpanan Data Berbasis Arduino," Med. Tek. J. Tek. Elektromedik Indones., vol. 1, no. 1, 2019, doi: 10.18196/mt.010103.

[3] N. H. Wijaya, B. Untara, and I. Khoirunnisa, "Monitoring Tekanan Gas Medis Pada Instalasi Gas Medis Rumah Sakit," Med. Tek. J. Tek. Elektromedik Indones., vol. 1, no. 1, pp. 2-7, 2019, doi: 10.18196/mt.010104.

[4] A. Bystritsky, L. Kerwin, and J. Feusner, "A pilot study of cranial electrotherapy for GAD," J. Clin. Psychiatry, vol. 69, no. 3, pp. 412-417, 2008.

[5] E. Loniza, H. Habiburrahman, and S. Ariwibowo, "Prototype Injeksi Insulin Pump Dengan Control Panel Arduino Uno," Med. Tek. J. Tek. Elektromedik Indones., vol. 1, no. 2, pp. 15, 2020, doi: 10.18196/mt.010206.

[6] M. Safitri, W. D. Iswara, and T. Harjono, "Blood Bag Shaker Dilengkapi Pemilihan Kecepatan Motor," Med. Tek. J. Tek. Elektromedik Indones., vol. 1, no. 2, 2020, doi: 10.18196/mt.010208.

[7] SUCI RAHMADYA, "Cranial Electrotherapy Stimulation," Poltekes Kemenkes Jakarta, 2008.

[8] M. F. Gilula and D. L. Kirsch, "Cranial electrotherapy stimulation review: A safer alternative to psychopharmaceuticals in the treatment of depression," J. Neurother., vol. 9, no. 2, pp. 7-26, 2005, doi: 10.1300/J184v09n02_02.

Medika Teknika : Jurnal Teknik Elektromedik Indonesia, Vol 03 No. 1, Oktober 2021 30 


\section{Firjatullah, Irfan}

Prototipe Cranial Electrotherapy Stimulation

[9] A. Datta, J. P. Dmochowski, B. Guleyupoglu, M. Bikson, and F. Fregni, "Cranial electrotherapy stimulation and transcranial pulsed current stimulation: A computer based high-resolution modeling study," Neuroimage, vol. 65, pp. 280-287, 2013, doi: 10.1016/j.neuroimage.2012.09.062.

[10] L. E. T. Nothing and S. You, cranial electrotherapy stimulator Owner'S Manual. 2201 Garrett Morris Parkway, USA: Electromedical Products International, Inc, 2017. 